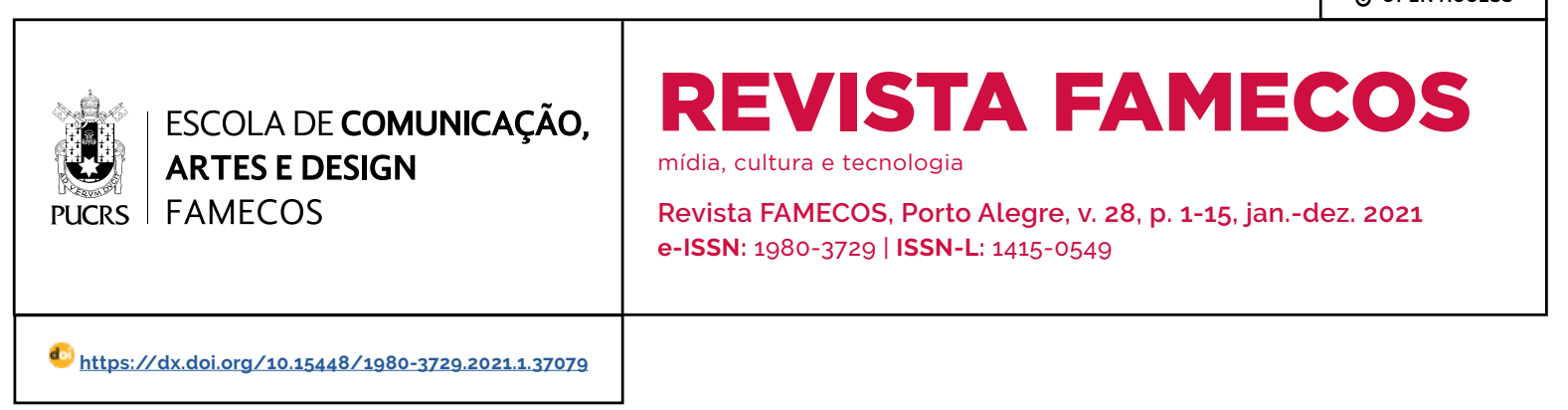

CINEMA

\title{
Identificação de esquemas de mise en scène em A história da eternidade
}

\author{
Identifying schemes of mise en scène in the feature The history of eternity \\ Identificación de esquemas de mise en scène en La historia de la eternidad
}

\author{
Bertrand Lira ${ }^{1}$ \\ orcid.org/0000-0003-1861-4281 \\ Lirabertrand@gmail.com
}

Recebido em: 13 fev. 2020. Aprovado em: 22 maio 2021. Publicado em: 8 jul. 2021.

\section{(c) (i)}

Artigo está licenciado sob forma de uma licença Creative Commons Atribuição 4.0 Internacional.
Resumo: Tendo o longa-metragem A história da eternidade (Camilo Cavalcante, 2014) como estudo de caso, buscamos identificar as estratégias formais adotadas pelo diretor na construção de sua narrativa. Essas escolhas constituem o que denominamos de mise en scène, procedimentos técnicos (e estéticos) que vão dar corpo à narrativa cinematográfica. Cineastas e estudiosos do cinema têm se dedicado à reflexão sobre a mise en scène desde as primeiras décadas da existência do cinema e, na contemporaneidade, esses estudos ainda despertam forte interesse entre teóricos como Bordwell (2013) e Aumont (2011), entre outros. Pretendemos demonstrar aqui, através de uma observação minuciosa de seus planos e cenas, que os esquemas de mise en scène empregados nesse filme, como longos planos fixos, poucos movimentos de câmera e a encenação em profundidade, por exemplo, distanciam dos procedimentos formais presentes nos filmes mainstream em diversas cinematografias mundiais.

Palavras-chave: Encenação em profundidade. Mise en scène. Estilo.

Abstract: This study aims to identifying the formal strategies chosen by the director in the construction of his narrative using the feature-length The History of Eternity (Camilo Cavalcante, 2014) as case study. These choices constitute the mise en scène, that is technical (and aesthetic) procedures that will reinforce the cinematographic narrative. The mise en scène have been intensely studied by filmmakers and scholars since the early decades of cinema, and, currently, these studies still arouse strong interest in theorists such as Bordwell (2013) and Aumont (2011), among others. Through a detailed analysis of the director shots and scenes, we intend to demonstrate that the mise en scène schemes applied in this film, such as long shots, few camera movements and frequent staging in depth of field, are different formal procedures from those present in mainstream films from worldwide cinematography.

Keywords: Staging in depth. Mise en scène. Style.

Resumen: Tomando el largometraje A história da eternidade (Camilo Cavalcante, 2014) como estudio de caso, buscamos identificar las estrategias formales adoptadas por el director en la construcción de su narrativa. Estos recursos constituyen lo que denominamos puesta en escena (mise en scène), procedimientos técnicos (y estéticos) que dan cuerpo a la narrativa cinematográfica. Cineastas y estudiosos han reflexionado sobre la mise en scène desde las primeras décadas de existencia del cine y, en la actualidad, su estudio todavía despierta gran interés entre teóricos como Bordwell (2013) y Aumont (2011), entre otros. Pretendemos demostrar aquí, a través de un análisis minucioso de sus planos y escenas, que los esquemas de puesta en escena empleados en esta película - largos planos fijos, escasos movimientos de cámara y con frecuencia composición de plano en profundidad, por ejemplo - se distancian de los procedimientos formales presentes en los filmes mainstream en diversas cinematografias mundiales.

Palabras clave: Puesta en escena en profundidad. Mise en scène. Estilo. 


\section{Introdução}

Ao longo da história do cinema, diretores, isolados, ou em grupos como integrantes de um movimento ou de uma escola, desenvolveram esquemas de mise en scène que conferiram a seus filmes uma aparência particular que remetia a um determinado estilo. No cinema contemporâneo, cineastas se identificam com certos esquemas estilisticos já historicamente consolidados em algumas cinematografias e, por afinidade, lançam mão dessas estratégias de encenação para usá-las como veículo de suas narrativas. São escolhas técnicas, a exemplo do foco profundo, que permite uma opção por uma encenação em profundidade só possivel, de forma deliberada, depois de 1925 com a produção de objetivas mais luminosas, já que a profundidade de campo nas imagens do primeiro cinema era uma determinante "natural" (MARTIN, 1990). Usaremos o conceito de estilo no sentido dado por Bordwell como "um uso sistemático e significativo das técnicas da midia cinema em um filme" (2013, p. 17) que abrangem o domínio da cinematografia, mise en scène, montagem (edição) e o som para analisarmos A história da eternidade (2014), primeiro longa-metragem do cineasta pernambucano Camilo Cavalcante, onde identificamos esquemas de encenação em profundidade e uso de longos planos-sequência fixos que o distanciam do esquema clássico da montagem em continuidade intensiva largamente utilizado no cinema mainstream contemporâneo.

Entendemos como um cinema mainstream aquele produzido por grandes estúdios, com altos orçamentos e estratégias de marketing para alcançar um grande número de espectadores além das fronteiras do país de origem, um tipo de produção que caracteriza o cinema produzido em larga escala, sobretudo, nos Estados Unidos. Mascarello observa que

Essa produção pós-1975 se define pelo abandono progressivo da pujança narrativa típica do filme hollywoodiano até meados de1960, e também por assumir a posição de carro-chefe absoluto de uma indústria fortemente integrada, dai em diante, à cadeia maior de produção e do consumo midiáticos (cinema, TV, vídeo, jogos eletrônicos, parques temáticos, brinquedos, etc.) (MASCARELLO, 2006, p. 336).
O cinema mainstream é marcado por esquemas de mise en scène que se consolidaram ao longo dos anos desde o surgimento da montagem em continuidade, procedimento que abandona, parcialmente, o plano longo fixo do primeiro cinema, a exemplo dos planos empregados nos curtas-metragens Viagem à lua (MÉLIĖS, 1902), A vida de um bombeiro Americano (PORTER, 1903) e dos demais que thes seguiram no chamado "primeiro cinema".

No contexto contemporâneo, do ponto de vista estético e narrativo, o cinema mainstream produz filmes que dão ênfase à rapidez da duração dos planos, como veremos mais adiante, na aceleração das ações da trama em detrimento do desenvolvimento e aprofundamento dos personagens, e na espetacularização da imagem com uso abundante de efeitos especiais, tendo sempre em vista um alcance abrangente e eficaz de público. Nos EUA, opuseram-se a essa estética os filmes denominados de art film, a exemplo de Nashville (ALTMAN, 1974), Taxi Drive, motorista de táxi (SCORCESE, 1976) e O portal do paraiso (CIMINO, 1980), citados por Mascarello (2006).

Lembramos que a oposição estética e ideológica ao cinema clássico, identificado como cinema hollywoodiano - um padrão estético denominado de Modelo de Representação Institucional (MRI) -, surge com as vanguardas nos anos 1920 (o cinema soviético, o impressionismo, o dadaísmo, o expressionismo etc.) e chega aos anos 1950 com os cinemas da modernidade na Europa do pós-guerra (neorrealismo italiano, nouvelle vague francesa e os novos cinemas mundiais, a exemplo do cinema novo brasileiro). No Brasil, com Glauber Rocha, o cinema novo vai radicalizar em uma oposição à estética hollywodiana nos anos 1960 e 1970.

É no contexto da nouvelle vague que surge o conceito de "cinema de autor" (VANOYE, GOLIOT-LÉTÉ, 1994). Um conceito problemático, como observam Aumont e Marie (2003, p. 26), para quem essa noção "demorou a aparecer historicamente e continua a ser flutuante conforme o pais e os modos de produção." Os autores enfatizam que

No âmbito da produção anônima dos estúdios, na produtora Pathé anterior a 1914 ou em Hollywood (1920-1960), era o próprio estúdio, na qualidade de entidade coletiva e imagem 
de marca, que podia ser considerado instância responsável pela criação da obra (2003, p. 26).

Enfatizamos aqui as condições de produção para que um diretor desfrute da total, ou quase total, liberdade de criação, pois "o status do autor no cinema está sempre ameaçado pela reação de forças entre o cineasta e as instâncias de produção e de difusão" (2003, p. 26). Se as condições de liberdade para a criação são imprescindiveis, não conferem, necessariamente, ao conjunto da obra cinematográfica de um diretor requisitos para o status de um cinema autoral. Este requer uso sistemático de procedimentos de mise en scène que imprimem marcas associadas a um determinado cineasta. Geralmente são esquemas não empregados com frequência no cinema dominante, nominado aqui de mainstream.

O filme de Cavalcanti, no âmbito da atual produção cinematográfica brasileira, enquadra-se em um conjunto de filmes realizados em um contexto, até então, de ampla liberdade de escolhas temáticas e estéticas visto que essas obras são subsidiadas por incentivos públicos, frutos de editais de fomento à atividade. São filmes de orçamentos muito aquém dos praticados no âmbito da indústria do audiovisual brasileiro por um número limitado de produtoras como a Globo Filmes, a O2 Filmes, Record Filmes e a Renato Aragão Produções Artísticas, por exemplo. Com o desmonte em andamento das políticas públicas para a cultura no governo Jair Bolsonaro, a partir de 2019, o setor cinematográfico vem se ressentindo de perdas de investimentos e da censura a temas considerados "inapropriados" pelo atual mandatário do país, com a configuração de um cenário de incertezas para o setor já que o grosso da produção nacional depende, sobretudo, do fomento público federal.

No filme em análise, identificamos esquemas de encenação que se repetem ao longo da narrativa, a exemplo de planos longos, escasso uso do recurso plano/contraplano - estratégia bastante banalizada ao longo da história do cinema; encenação em profundidade, poucos movimentos de câmera, entre outros. Observaremos nesta abordagem a quantidade de vezes que o diretor (metteur en scène) lança mão dessas estratégias técnicas (e estéticas) para materializar em imagens e sons a narrativa proposta pelo roteiro. O conceito de mise en scène difere em autores como Aumont (2011), Bordwell (2013, 2008) e Oliveira Jr. (2013), por isso apresentamos aqui brevemente o ponto de vista desses autores ante de iniciarmos a análise do filme proposto. Bordwell, por exemplo, entende a cinematografia como uma "variável independente" (2008, p. 36) da mise en scène, incluindo nesse conceito apenas o que diz respeito ao domínio da cena, isto é, a direção de atores, seus movimentos, falas, expressões, gestos, figurino, maquiagem, cenário e sua iluminação.

Em O cinema e a encenação, Aumont (2011) vai encontrar a origem do termo no teatro por volta de 1820, traçando o longo percurso do conceito a partir da sua utilização no cinema, elencando reflexões de teóricos e cineastas, a exemplo de Urban Gad, que em uma extensa publicação aborda o cinema em todos os seus domínios, inclusive sobre formas de encenação cinematográfica. No entender de Luis Carlos Oliveira Jr., a "mise en scène não progride cronologicamente na história do cinema, não evolui linearmente: ela se dá em decorrência da finalidade de cada narrativa, do tipo de cinema a que serve, do material em que se baseia" (2013. p. 28). Na presente abordagem, vamos trabalhar o conceito a mise en scène cinematográfica como entendido por François Truffault. Para o cineasta, a mise-en-scène compreende "a posição da câmera, o ângulo selecionado, a duração da tomada, o gesto do ator, [...] simultaneamente a história que está sendo contada, a maneira de contá-la" (apud BORDWELL, 2008, p. 34).

O estabelecimento da continuidade narrativa com a mobilidade da câmera e a adoção de vários pontos de vista sobre a cena (a decupagem clássica) é creditada pelos historiadores a D. W. Griffith a partir de 1915. Em determinados periodos históricos, diferentes esquemas foram empregados por diretores de cinematografias diversas.

Nem bem Griffith havia, nas suas linhas básicas e na sua versão muda, consolidado esse método, a denúncia de seus limites já surgia. O que não impediu que, sob a observância de 
seus principios, décadas de cinema ficassem marcadas pelo predomínio absoluto deste método de narração no nivel da produção industrial em escala mundial, sem exceções (XAVIER, 2005, p. 37).

Mesmo com a recusa a essa forma predominante de representação institucional do cinema pelos movimentos vanguardistas europeus nos anos 1920, alguns esquemas clássicos se fizeram presentes mesmo nos filmes com propostas "não narrativas" de algumas vanguardas e nos cinemas da modernidade do pós-guerra. Bordwell chama de esquemas "práticas bem padronizadas, rotinas estilisticas" (2008, p. 25) adotadas pelos cineastas em suas sobras. Alguns esquemas, abandonados por certo período de tempo, são retomados e reciclados em contextos outros.

Os cineastas herdam, observam, impregnam-se, citam, parodiam, plagiam, desviam, integram as obras que precedem as suas. Alguns elementos fílmicos que se acreditava ultrapassados, desaparecidos, foram retomados [...], mas em contextos diferentes, as formas e as significações, com isso, automaticamente renovadas (VANOYE; GOLIOT-LÉTÉ, 1994, p. 36-37).

É o que pretendemos verificar em A história da Eternidade (2014), longa-metragem de Camilo Cavalcante, que retoma esquemas de encenação que passam ao largo da mise en scène do cinema dominante, afastando-se, de um modo geral, das suas clássicas estratégias narrativas de campo/ contracampo, da montagem em continuidade intensiva, entre outros esquemas banalizados pelas narrativas do cinema produzido em larga escala industrial e vulgarizadas nas narrativas ficcionais televisivas, sobretudo nas telenovelas.

$\mathrm{Na}$ cinematografia mundial, alguns dos esquemas utilizados por Cavalcante (a encenação em profundidade, o primeiro plano vazio, planos longos, por exemplo) estão presentes, particularmente, na filmografia do japonês Kenji Mizoguchi dos anos 1930 a 1950: Elegia de Osaka e As irmãs de Gion (1936), O amor de Sumako (1947) e Contos da lua vaga depois da chuva (1953); no grego Theo Angelopoulos de Paisagem na Neblina (1988) e de O passo suspenso da cegonha (1991); e no taiwanês Hou Hsiao Hsien de Um tempo para viver, um tempo para morrer
(1985) e Cidade das tristezas (1989), para citar alguns filmes emblemáticos desses diretores analisados por Bordwell (2008). Em relação ao uso de planos longuíssimos ("slow cinema"), há diretores como Apitchatpong Weerasekthakul, em Eternamente sua (2002), por exemplo, que radicaliza na proposta de fazer coincidir o tempo cronológico e o tempo diegético (OLIVEIRA JR., 2013). E no cinema brasileiro contemporâneo, alguns desses esquemas podem ser vistos nos filmes de Cláudio Assis (Baixio das Bestas, 2007), Marcelo Gomes (Joaquim, 2017) e de Karim Aïnouz ( $A$ vida invisivel, 2019), entre outros.

\section{Alguns esquemas de mise en scène em A história da eternidade}

\section{A duração média dos planos (DMP) e o plano-sequência}

Na abertura de A história da eternidade, dois longos planos gerais fixos indicam as opções de encenação que o diretor Camilo Cavalcante nos apresentará no decorrer da narrativa. No primeiro, temos um plano geral do céu até que um garoto entra no quadro com seu estilingue e dispara contra um pássaro que voa. O segundo enquadra um sanfoneiro que toca a música dolente que começamos a ouvir logo após os créditos iniciais do filme, cuja tela permanece escura por 50 segundos até o fade in que revela a cena inicial. Com a câmera impassivel, o drama se desenrola à sua frente: o garoto que abate o pássaro (Imagem 1), o acordeonista que toca e a passagem de um cortejo fúnebre de uma criança que atravessa o quadro (Imagem 2), ao modo de um tableau, definição dada pelos franceses a um plano único fixo com a câmera colocada de frente para a cena. Logo após esse tableau, um corte seco nos leva a um plano fechado dos pés de um homem que cava uma sepultura. São mais dois planos fechados para apresentar duas personagens-chave da narrativa até voltarmos para os planos gerais. O último, em câmera alta, dura aproximadamente um minuto. Plano-sequência e plano longo são termos que se confundem. Para Aumont e Marie, "Tal distinção, porém, no mais das vezes, é dificil, e geralmente fala-se de plano- 
-sequência quando um plano é suficientemente longo." (2003, p. 231). Trataremos aqui o termo plano- sequência como o concebe Bordwell, isto é, "quando uma cena inteira é apresentada

\section{Imagem 1 - Primeiro plano longo}

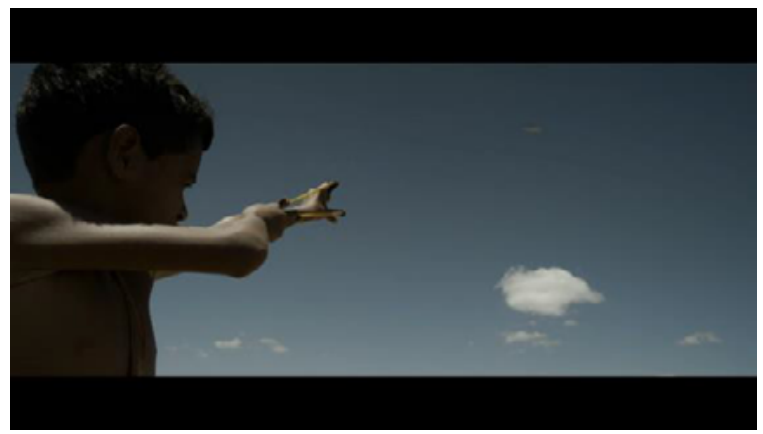

Fonte: Frame do filme A história da eternidade (2014).

Em aproximados oito minutos de filme, a extensão dos planos varia de 15 a 31 segundos de duração, bem acima da duração média dos planos (DMP) do cinema mainstream contemporâneo. Para se ter uma ideia de quanto a duração média dos planos diminuiu ao longo da história do cinema, Bordwell (2008) observou os filmes hollywoodianos a partir dos anos 1930, com o estabelecimento definitivo do cinema sonoro, e verificou que, até a década de 1960, a maioria deles apresentava uma DMP de oito a 11 segundos, com um número de planos variando entre $300 \mathrm{e}$ 700. Essa rapidez nos cortes é uma tendência do cinema mainstream, sobretudo o norte-americano (um sistema de produção, distribuição e exibição dominante). Como constata o autor, a partir da década de 1990, essa rapidez nos cortes chegou a uma DMP de dois a oito segundos com filmes que apresentam mais de dois mil planos.

No filme em questão, uma cena apenas segue, mais ou menos, esse padrão de planos curtos que é, contudo, justificada por uma ação da personagem Alfonsina (Débora Ingrid): contemplativa e olhar sonhador, ela acende a apaga a luz da luminária imprimindo um ritmo regular aos planos detalhes de objetos de decoração de seu quarto (bibelôs, um rádio de pilhas, rolos de linhas de crochê, fotos de praias etc.) que também inclui um largo painel de fotografias na parede antecipando ao espectador o desejo da adolescente de conhecer o mar. Essas em um único plano, o plano longo é conhecido pelo termo plano sequência" (2013b, p. 334, grifo do autor). É o caso da passagem do cortejo que dura dois minutos e 51 segundos.

Imagem 2 - Segundo plano longo

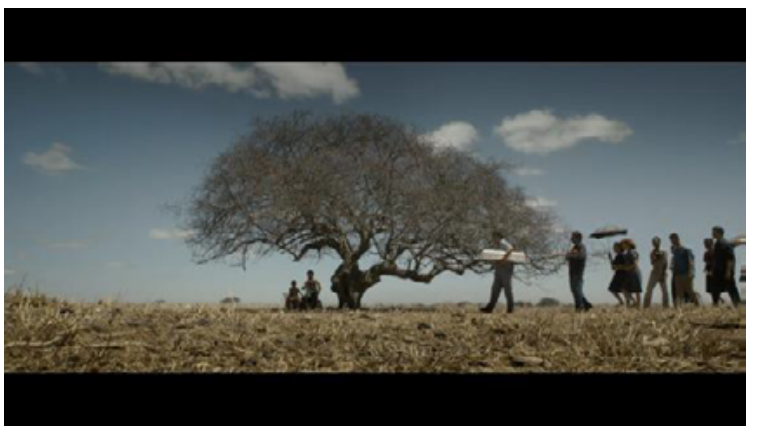

Fonte: Frame do filme A história da eternidade (2014).

imagens aparecem e desaparecem ao clicar de um interruptor de mão em um ritmo cadenciado. $A$ cena termina com a entrada brusca do irmão que desliga o rádio, fonte sonora (diegética) da música romântica que Alfonsina escuta.

A trama de A história da eternidade envolve o drama de seis personagens, três delas mulheres: uma idosa, Dona das Dores; uma mulher madura, Querência; e uma adolescente, Afonsina; e três homens: Joãozinho e Nataniel, tio e pai de Alfonsina; e Aderaldo, o pretendente de Querência. Os personagens vivem em um vilarejo ermo no sertão nordestino. De uma forma ou de outra, essas histórias se cruzam, pois o espaço onde se desenvolvem é bem circunscrito. Querência (Marcélia Cartaxo) acaba de perder o filho, é abandonada pelo companheiro e vive o seu luto sem fim enquanto é assediada por um sanfoneiro cego, Aderaldo (Leonardo França), apaixonado por ela. O drama de Alfonsina (Débora Ingrid) é o desejo pelo tio Joãozinho (Irandhir Santos), artista deslocado daquele ambiente e que vive às custas do irmão rude Nataniel (Cláudio Jaborandy) que o humilha o tempo todo. O desejo incestuoso perpassa também o drama de Das Dores (Zezita Matos) que abriga o neto Geraldinho (Maxwell Nascimento), um foragido, sem que ela saiba.

Com raras exceções, a opção geral de mise en scène de Camilo Cavalcante é por uma maior duração dos planos e pela imobilidade da câ- 
mera com o uso predominante de planos fixos, a exemplo das duas primeiras cenas iniciais do filme. Para Oliveira Jr., o plano longo "valoriza a duração da cena que não pode ser forjada na montagem, mas, sim, vivida no set, experimentada pelos atores com interrupções mínimas" (2013. p. 79). As cenas que dão corpo à narrativa de Cavalcante são abundantes em planos longos, distanciando da montagem baseada na continuidade intensificada onde os cortes são frequentes, fragmentando a cena. Os três planos longos que dão forma à cena do jantar na casa de Alfonsina ilustram o que diz Oliveira Jr. acima.

Na sala da modesta casa, a família (o pai Nataniel e os quatro filhos rapazes) encontra-se à mesa enquanto Alfonsina entra e sai do quadro para lhes servir o jantar. Esse plano dura um pouco mais de um minuto até que a câmera muda de eixo em $180^{\circ}$ para mostrar Alfonsina em pé, agora de frente, na mesma posição do plano anterior, como uma servente, observando pai e irmãos comerem. Ao todo, com apenas três planos, a cena com duração de um minuto e 34 segundos, é marcada pelas poucas falas e com duração média de 31 minutos por plano.

Utilizamos aqui o conceito de duração média do plano de Bordwell que "se baseia em assistir ao filme inteiro e dividir seu tempo de duração em segundos pelo número de tomadas. Tanto as imagens quanto os intertítulos são considerados tomadas, mas os créditos da produção, não" (2008, p. 47). Apesar de Bordwell mesclar, alternadamente, os termos tomada e plano, optamos por trabalhar aqui o termo plano como elemento estrutural do filme quando da sua montagem. A duração média dos planos (DMP) em A História da Eternidade é de aproximadamente 25 segundos. $O$ filme tem mais ou menos 260 planos. Consideramos a duração total do filme em 110 minutos (660 segundos), não contabilizando os dez minutos dedicados aos créditos iniciais e finais. Uma DMP de 25 segundos desvia da tendência dominante no cinema mainstream, sobretudo quando associada ao esquema de planos-sequência fixos.

Vamos encontrar nesse filme usos recorrentes de planos longos fixos e com pouca variação de ponto vista. Enfatizaremos aqui alguns deles como emblemáticos da opção de mise en scène de Cavalcante. A cena inicial, como vimos, a do sanfoneiro e do cortejo fúnebre, tem duração de dois minutos e cinquenta segundos. Ela dá o tom do restante da mise en scène adotada com o uso de planos longos fixos que variam de 30 a 40 segundos. Em certos momentos, temos variações entre um e dois minutos na duração dos planos. Na cena da chegada de Aderaldo à casa de Alfonsina, até que ela abra a porta, por exemplo, o plano dura um minuto. A partir daí acontece alternância de pontos de vista com planos aproximados e montagem em plano/ contraplano com variações na duração de aproximadamente 20 a 30 segundos (Imagens 3, 4 e 5). O primeiro uso desse esquema se dá aos 14 minutos de narrativa na cena em que Alfonsina conversa com o tio, igualmente à janela (Imagens 6 e 7), como uma "rima visual". Mas o uso da montagem continuada não é uma marca do estilo do diretor nesse filme. Temos outro momento em que a montagem é picotada em um diálogo à mesa de Das Dores e seu neto, ora mostrando o rosto de um e do outro, não exatamente em plano e contraplano, mas enquadramento frontal isolado do neto e lateral da avó ou dos dois no mesmo quadro (Imagens 8, 9 e 10).

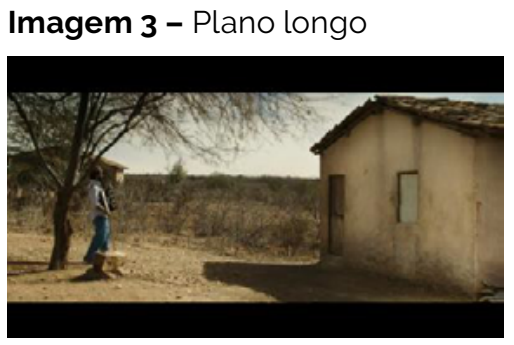

Fonte: Frame do filme $A$ história da eternidade (2014).

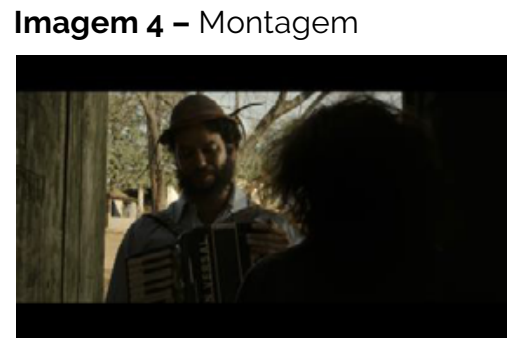

Fonte: Frame do filme $A$ história da eternidade (2014).
Imagem 5 - Montagem

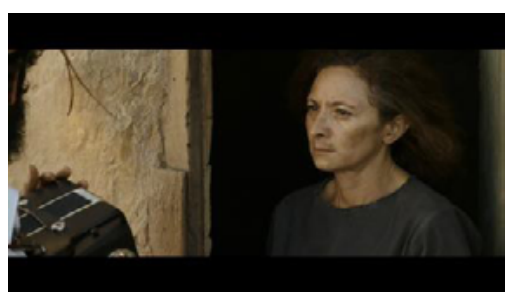

Fonte: Frame do filme A história da eternidade (2014). 
Imagem 6 - Esquema de plano/contraplano à janela Imagem 7 - plano/contraplano ("rima visual")

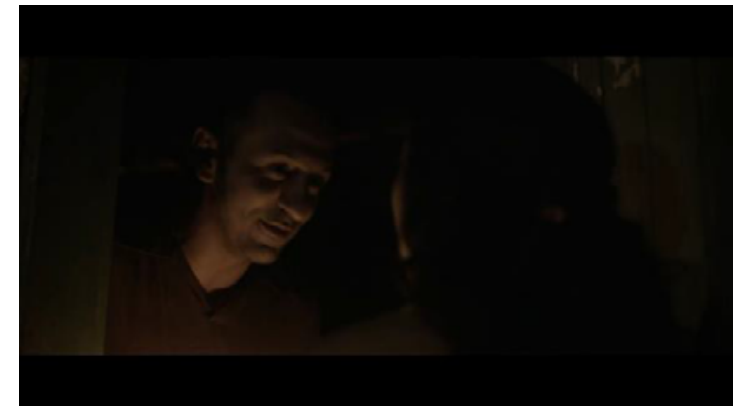

Fonte: Frame do filme A história da eternidade (2014)

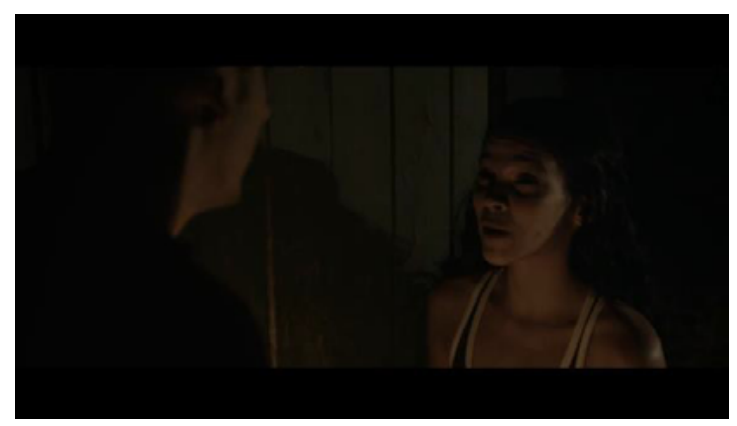

Fonte: Frame do filme A história da eternidade (2014)

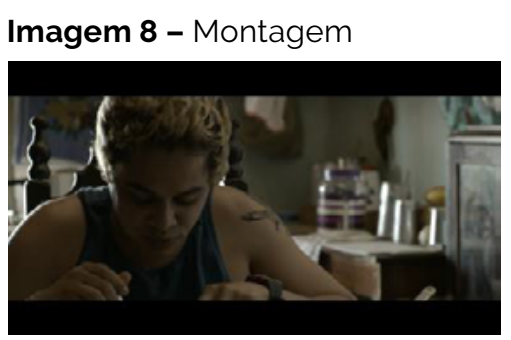

Fonte: Frame do filme A história da eternidade (2014).
Imagem 9 - Montagem

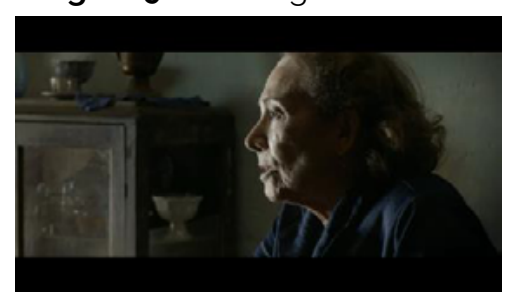

Fonte: Frame do filme $A$ história da eternidade (2014).
Imagem 10 - Montagem

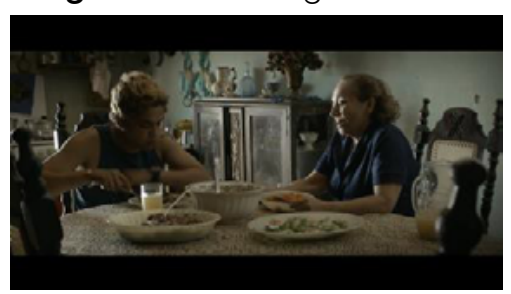

Fonte: Frame do filme A história da eternidade (2014).
Entre outros planos considerados nesta análise pela longa duração, assinalamos a cena do bar onde os seis planos que a integram têm duração que vai de 30 a 50 segundos, com quatro deles lançando mão da encenação em profundidade, como mostraremos na sessão dedicada a esse esquema logo a seguir. Um plano longo, com exatos 60 segundos, que se inicia fixo e depois se torna movente (com um travelling para a frente), intensifica o drama do ataque de epilepsia de Nataniel. O plano seguinte, também distanciado da ação, dura quase 40 segundos. O plano mais longo do filme, no entanto, tem extensão de tem- po de três minutos e acontece na cena seguinte, quando Nataniel, sozinho, na sala escura, desperta da crise (Imagens 11, 12 e 13). Nesse plano fixo, o diretor aposta na coreografia dos atores no quadro: primeiro a de Nataniel, que se arrasta para a parte frontal da cena, e depois a de Alfonsina, que entra lateralmente da esquerda para a direita sem, no entanto, encobrir o tio. Soluções de mise en scène como essa (encenação em profundidade), como assinala Bordwell (2008, 2013), eram usadas pelos diretores mais criativos dos anos 1910, a exemplo do francês Louis Feuillade.

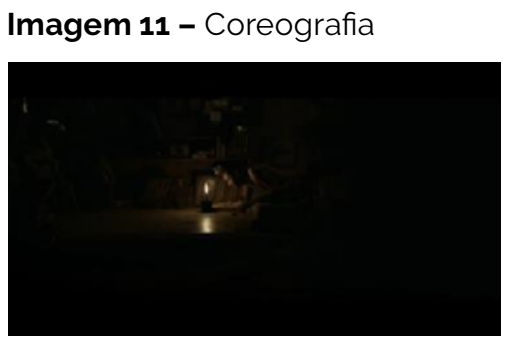

Fonte: Frame do filme A história da eternidade (2014).
Imagem 12 - Coreografia

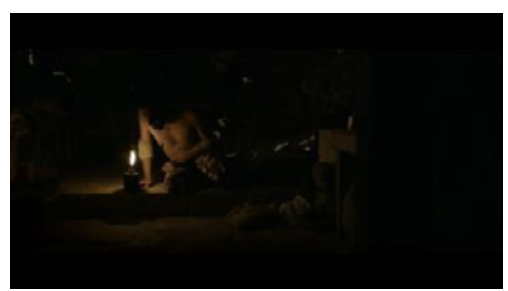

Fonte: Frame do filme A história da eternidade (2014).

\section{Imagem 13- Coreografia}

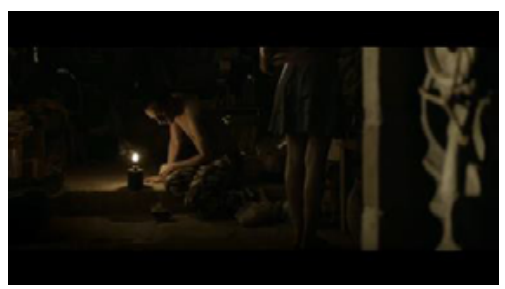

Fonte: Frame do filme A história da eternidade (2014).
Para Martin, o plano-sequência "permite uma dramatização interna da imagem, ao valorizar a continuidade temporal da ação" (2007, p. 265). Ao optar pela utilização de planos longos para representar uma ação ou parte dela, os diretores têm suas razões, uma delas é permitir ao olhar do espectador uma exploração do conteúdo do quadro representado (iluminação, objetos, figurino 
e demais indicadores da encenação) sem impor obrigatoriamente um direcionamento do olhar. Não negligenciamos aqui o papel da iluminação e da composição nessa tarefa de organizar o quadro, realçando aspectos da cena a serem vistas por sua importância na compreensão da narrativa. Neste sentido, argumentam Bordwell e Thompson:

[...] os planos longos tendem a ser enquadrados em planos médios ou de conjunto. A câmera se demora em um campo visual razoavelmente denso e o espectador tem mais oportunidades de analisar o plano em buscas de pontos especificos de interesse (2013, p. 335).

\section{A encenação em profundidade}

Técnica utilizada pelo cinema desde a década de 1910, a encenação em profundidade foi aperfeiçoada pelo exercício contínuo dos cineastas na busca da melhor forma de narrar suas histórias e sensibilizar o espectador. Também nos referimos a essa técnica como composição em profundidade de campo.

Clareza, ênfase e mudanças de atenção a cada momento não eram os únicos objetivos da nova encenação em profundidade. [...] A encenação em profundidade dos anos 1910 era uma resposta à necessidade, comum entre artistas de todos os lugares e tradições, de moldar o material para obter efeitos específicos no espectador (BORDWELL, 2013, p. 269).

Em A história da eternidade, a chegada de Querência à festa de aniversário de Alfonsina é trabalhada por um jogo de esconde e revela, pois a coreografia dos corpos da gente que dança permite a visualização da recepção de Alfonsina e Das dores à Querência ao fundo. Toda a movimentação dos pares que dançam no salão é ensaiada para esse jogo de esconde e revela da inesperada presença de Querência, até então presa ao seu luto. Na imagem 14, Das Dores encobre Alfonsina. Querência está fora de foco, mas temos certa inteligibilidade ao longo da cena. É a chamada "encenação em profundidade sem foco". Esta estratégia proporciona o elemento surpresa da aparição da personagem. Na imagem 15, um casal passa dançando e encobre a ação que logo em seguida é desvelada e vemos as três mulheres conversando animadas. Elas ficam praticamente emolduradas pelos músicos e a gente do salão (Imagem 16).
Imagem 14 - Encenação em pro- Imagem 15 - Ocultação da ação fundidade sem foco

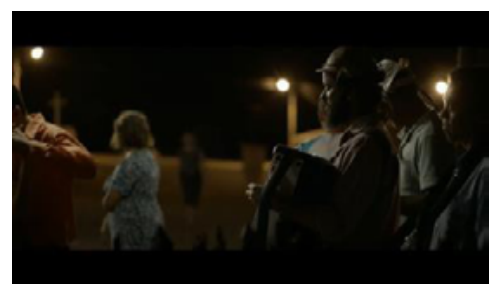

Fonte: Frame do filme $A$ história da eternidade (2014).

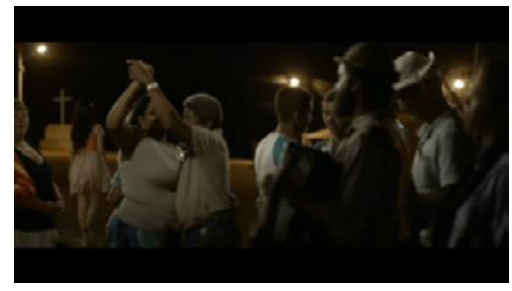

Fonte: Frame do filme $A$ história da eternidade (2014).
Imagem 16 - Revelação: encenação em profundidade

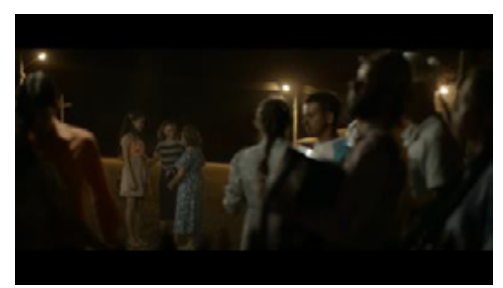

Fonte: Frame do filme $A$ história da eternidade (2014).
Outra forma elaborada de enfatizar uma encenação em profundidade, empregada em alguns momentos de A história da eternidade, é o uso de artifícios como o enquadramento da ação principal através de molduras de portas e janelas em primeiro plano. A composição com molduras, um dos elementos de estilo na cinematografia japonesa, está presente fortemente na obra do cineasta Kenji Mizoguchi. "Com essa estratégia, o diretor potencializava qualquer brecha do quadro e recompensava o espectador por sua observação minuciosa do campo complexo, sem esquecer de incluir outros aspectos expressivos da ação principal" (BORDWELL, 2008, p. 145-146).

Apresentamos três exemplos dessas estratégias empregadas aqui para reforçar a profundidade da cena. A primeira delas é o emolduramento da ação com a utilização de uma porta (Imagem 17), a segunda, com o preenchimento do espaço frontal usando um primeiro plano com objetos de cena em destaque, aqui jarro com flores, espaldar da cadeira, móvel abarrotado de adereços e a parede de fotografias (Imagem 18). 
Imagem 17 - Parede como moldura

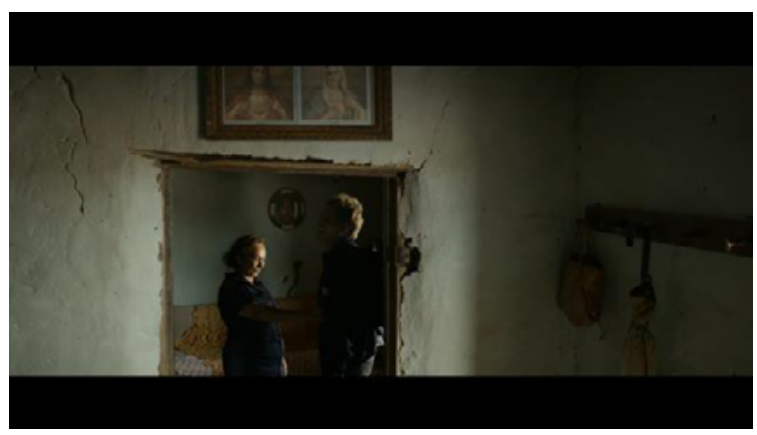

Fonte: Frame do filme A história da eternidade (2014).

Noutra cena, no bar, além do plano distante, temos um pilar emoldurando duas ações: em um plano frontal, à esquerda do quadro, Nataniel à mesa bebendo com amigos e, à direita, dois jogadores de bilhar (Imagem 19).

A cena está simetricamente dividida e assistimos simultaneamente duas ações. As falas vêm do "quadro" à esquerda, de Nataniel que filosofa

Imagem 19 - Pilares como molduras

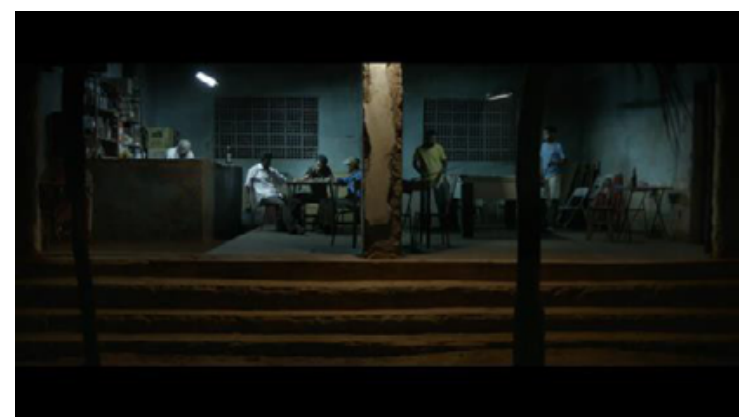

Fonte: Frame do filme A história da eternidade (2014).

No exemplo a seguir, uma janela emoldura a ação em mais um esquema de encenação em profundidade. Joãozinho prepara sua performance que desencadeará um outro atrito com o irmão $\mathrm{Na}$ taniel. Além da moldura proporcionada pelajanela e da grande profundidade de campo com toda a extensão da imagem em foco, o deslocamento dos

\section{Imagem 18 - PP com objetos de cena}

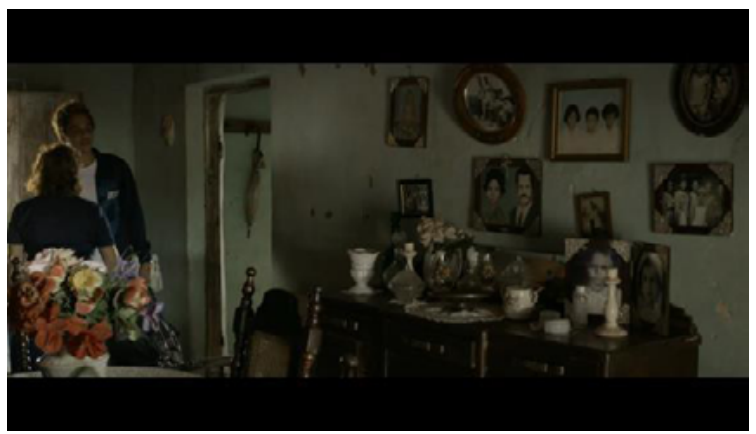

Fonte: Frame do filme A história da eternidade (2014).

sobre a ingratidão. Dos jogadores à direita, ouvimos apenas ruidos dos tacos que tocam as bolas. Na mudança de enquadramento, para um plano lateral de conjunto, podemos visualizar novamente as duas ações. Dessa vez, a mesa de bilhar e um dos seus jogadores compõem um primeiro plano arrojado tendo ao fundo a ação principal (Imagem 20) de onde um conflito iminente eclodirá.

\section{Imagem 20 - Primeiro plano arrojado}

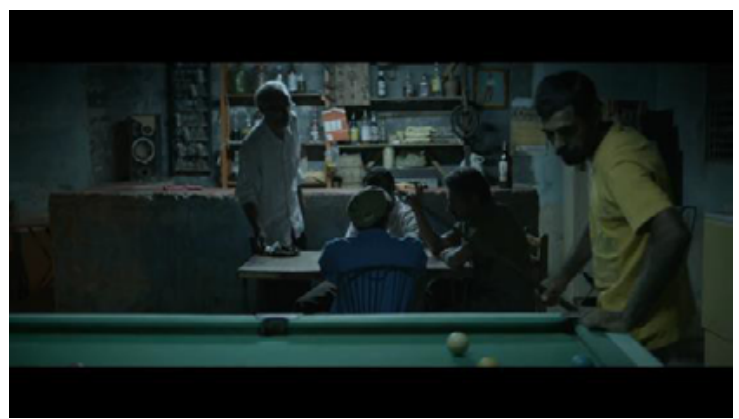

Fonte: Frame do filme A história da eternidade (2014).

personagens em cena acentua essa profundidade. Primeiro é Joãozinho que se aproxima dajanela (ou seja, do plano frontal, nas imagens 21 e 22) e depois é Nataniel que surge do fundo da cena e se desloca para o primeiro plano em um movimento em paralelo ao eixo da câmera acentuando a profundidade de campo (PC) da imagem (Imagens 23, 24 e 25). 


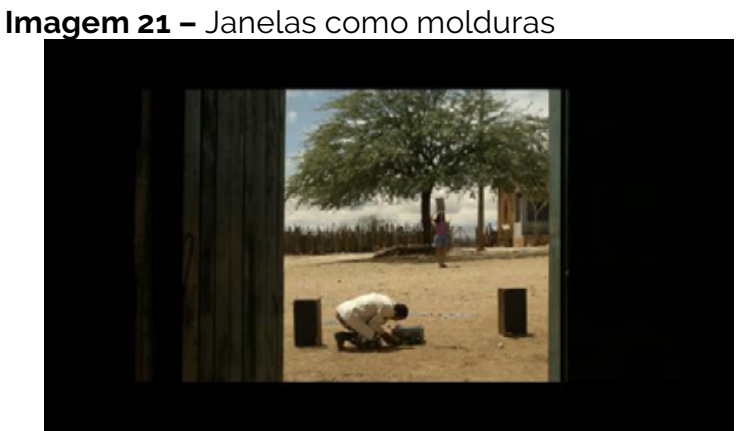

Fonte: Frame do filme A história da eternidade (2014).

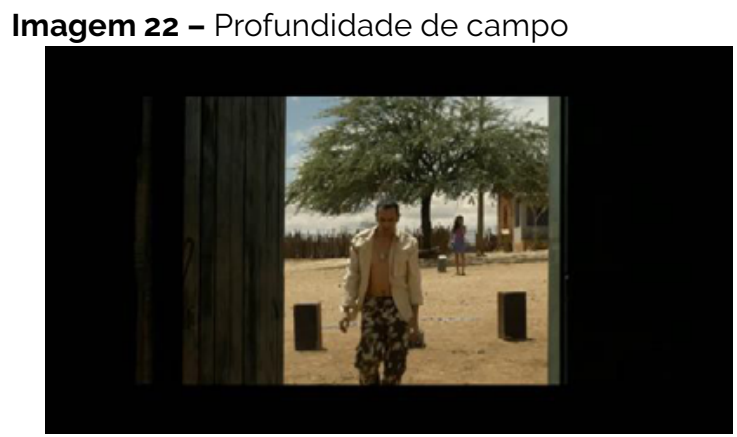

Fonte: Frame do filme A história da eternidade (2014).

Imagem 23 - PC acentuada pela Imagem 24-Ação em movimento Imagem 25-PC Movimento longiação

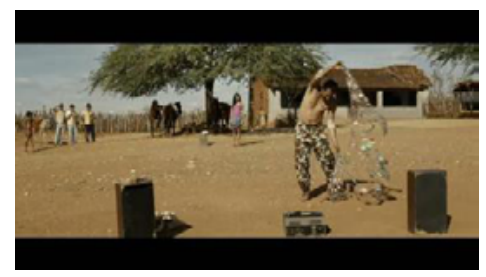

Fonte: Frame do filme $A$ história da eternidade (2014).

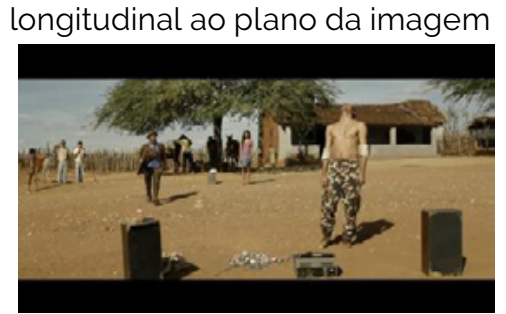

Fonte: Frame do filme $A$ história da eternidade (2014). tudinal ao plano da imagem

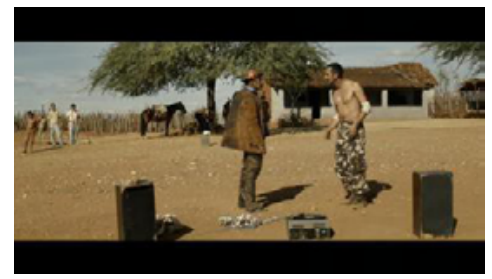

Fonte: Frame do filme A história da eternidade (2014).
Apresentamos aqui, em uma mesma cena, os dois esquemas de mise en scène discutidos acima (o plano longo fixo e a encenação em profundidade) e usados na cena final do baile de aniversário de Alfonsina que termina de forma patética: Nataniel interrompendo a dança de Alfonsina e do tio Joãzinho e chorando ajoelhado aos pés da filha lhe pedindo perdão. A câmera se posiciona distanciada da cena, o que contribui de certa forma a arrefecer o drama. A tomada tem exatos 60 segundos, do momento que Alfonsina abandona a festa até o fade out que interrompe a reação dos presentes. Um fade out "diegético" porque são as luzes dos dois ambientes que vão pouco a pouco se apagando (Imagens 26, 27 e 28).
Imagem 26 - Encenação em pro- Imagem 27 - Plano longo fixo fundidade

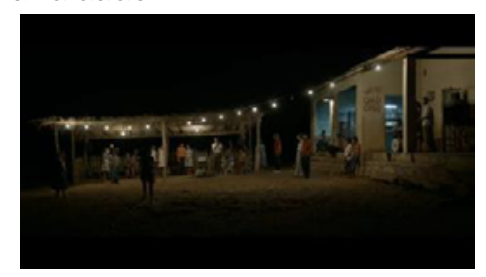

Fonte: Frame do filme $A$ história da eternidade (2014).

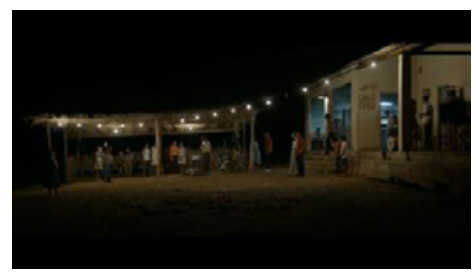

Fonte: Frame do filme A história da eternidade (2014).
Imagem 28 - Fade out diegético

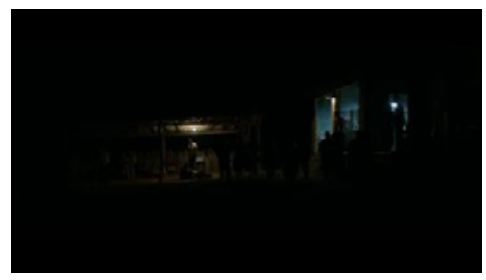

Fonte: Frame do filme A história da eternidade (2014).
Assim, a encenação em profundidade é alcançada pelo uso do foco em diversas áreas da imagem, quer com o emprego de objetivas que "naturalmente" proporcionam um foco profundo, a exemplo das grandes- angulares, quer com o uso de objetivas normais ( $50 \mathrm{~mm}$ ) com a seleção do número de diafragma maior (f/16 ou f/22, por exemplo). Uma estratégia que contribui para re- forçar a profundidade de uma cena é colocar a ação dramática em planos posteriores e compor a cena em camadas, distribuindo elementos de cena ao longo de sua extensão longitudinal. Uma composição do quadro com molduras naturais do cenário (portas, janelas etc.) também tem sua importância nesse esquema de mise en scène. 


\section{Movimentos de câmera}

Uma mise en scène que lança mão de movimentos de câmera permite uma economia na etapa da montagem, fazendo a decupagem na tomada, isto é, durante o próprio movimento afastando-se ou se aproximando da ação, como podemos verificar na cena do ataque epiléptico de Joãozinho, quando a câmera avança de um plano geral para um plano mais aproximado das três mulheres que socorrem o artista, enfatizando o drama sem interromper seu fluxo. Ou quando a câmera em um travelling para a frente chega mais próximo de Alfonsina encantada com a performance do tio (Imagens 29, 30 e 31). Se- gundo Martin, "o travelling para frente "exprime. objetiva e materializa a tensão mental (impressão, sentimento, desejos e ideias violentos e súbitos) de um personagem" (2007, p. 50, grifo do autor).

Aliás, o movimento de câmera nesta cena tem uma função descritiva e ao mesmo tempo rítmica. Ao dar voltas em torno do artista durante sua performance, ela vai descrevendo uma ação (a dança) e revelando a reação dos moradores do lugar que progressivamente vão se aproximando para assistir à apresentação. Temos uma repetição desse movimento em torno dos personagens (um plano-sequência de um pouco mais de 2 minutos) na cena em que Joãozinho faz Alfonsina "ver o mar".

Imagem 29 - Movimento de câme- Imagem 30 - Travelling para frente... ra circular descritivo

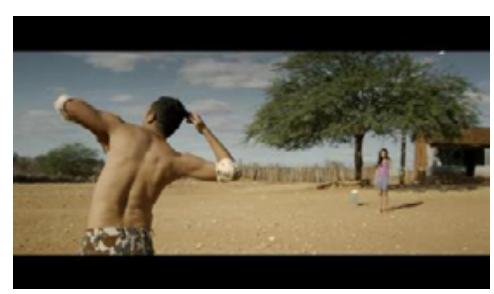

Fonte: Frame do filme A história da eternidade (2014).

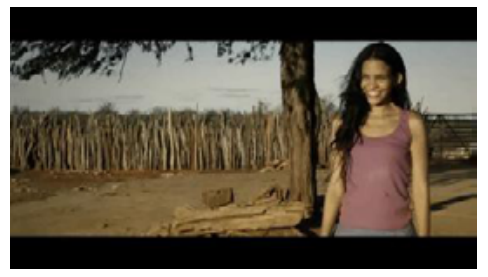

Fonte: Frame do filme A história da eternidade (2014).
Imagem 31 - Para explicitar a reação da personagem

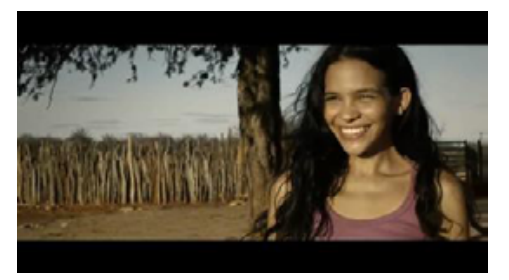

Fonte: Frame do filme $A$ história da eternidade (2014).
Há um momento na sequência da festa que a câmera descreve cinco pequenas ações ao ritmo da música romântica (diegética) que os personagens escutam. Temos um travelling descritivo que vai da esquerda para a direita mostrando o espaço e as ações dos diversos personagens presentes (Imagens 32 e 33); um travelling para a frente ressaltando a embriaguez de Nataniel (Imagem 34); um travelling para trás afastando-se de Das Dores e do neto que lhe dá assistência; um lateral que mostra a alegria de Querência; um travelling suave que acompanha Alfonsina e o tio que dançam romanticamente (Imagens 35.
36 e 37). "O movimento de câmera se torna assim crucial, já que ele muitas vezes pode substituir o corte e a mudança de plano na tarefa de permitir um novo ângulo, uma nova distância, uma nova composição, enfim, um novo acesso à cena" (OLIVEIRA JR., 2013, p. 79, grifo do autor). Assim, é o que nos proporciona esse movimento no instante em que Nataniel, vendo a filha e o tio dançando, levanta-se irritado do bar e se dirige decidido ao salão para separá-los. A câmera o acompanha à distância em um plano-sequência de mais ou menos um minuto de duração (Imagens 38, 39 e 40).

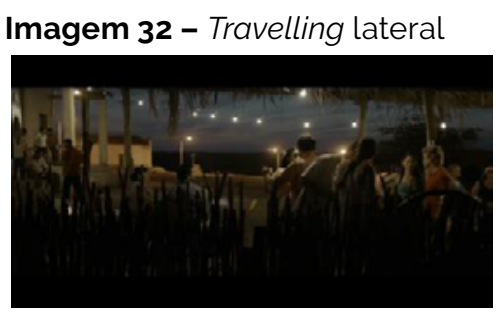

Fonte: Frame do filme A história da eternidade (2014).

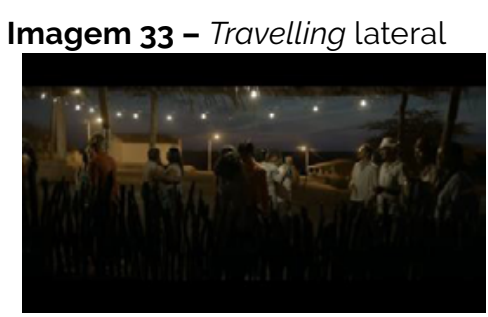

Fonte: Frame do filme A história da eternidade (2014).

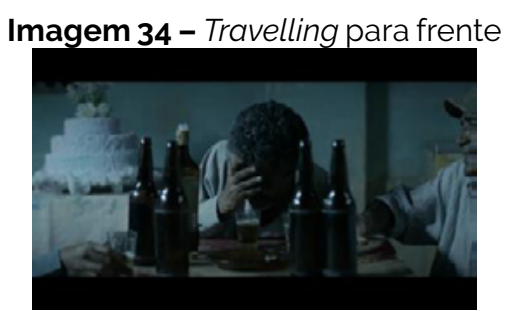

Fonte: Frame do filme $A$ história da eternidade (2014). 


\section{Imagem 35 - Travelling para trás Imagem 36 - Travelling lateral}

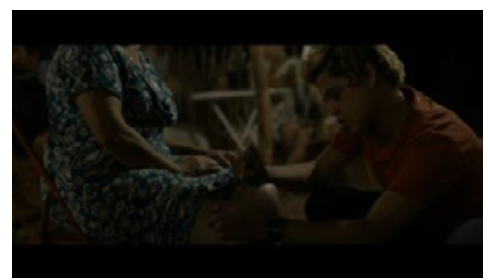

Fonte: Frame do filme A história da eternidade (2014).

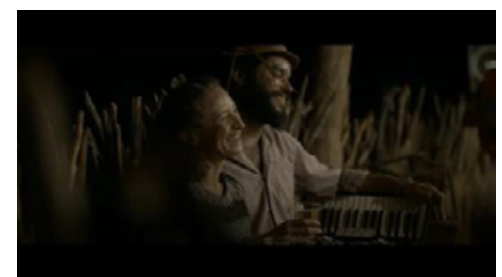

Fonte: Frame do filme A história da eternidade (2014).
Imagem 37 - Travelling para acompanhamento

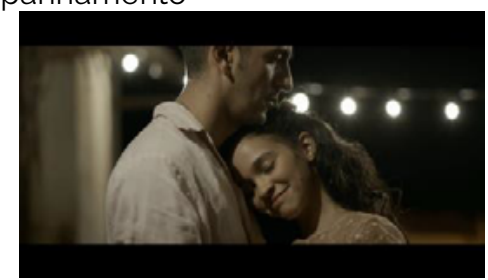

Fonte: Frame do filme $A$ história da eternidade (2014).
Imagem 38 - Movimento substi- Imagem 39 - Movimento substituindo a montagem (início)

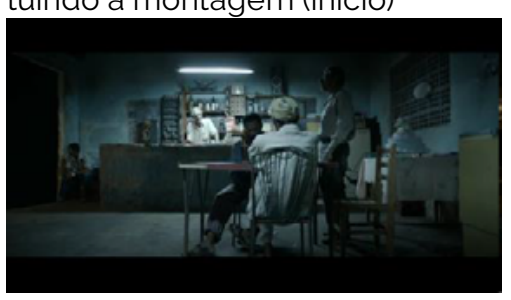

Fonte: Frame do filme $A$ história da eternidade (2014) tuindo a montagem (meio)

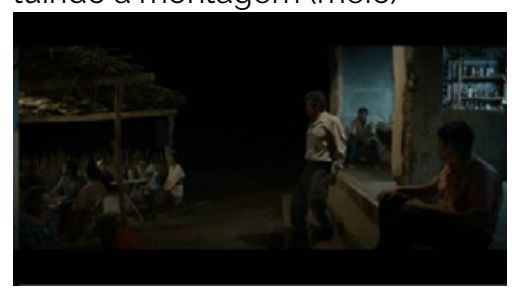
eternidade (2014).
Fonte: Frame do filme A história da
Imagem 40 - Movimento substituindo a montagem (final)

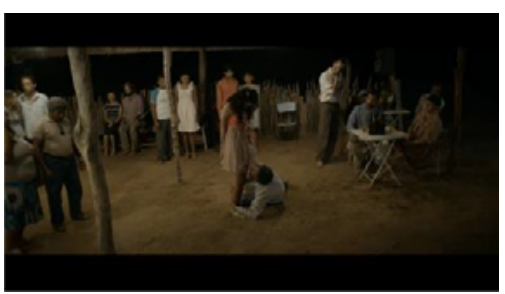

Fonte: Frame do filme A história da eternidade (2014)
Percebemos que apesar do uso de diferentes movimentos de câmera (travellings e panorâmicas) ao longo de A história da eternidade, a mise en scène empregada para dar forma ao filme enfatiza planos longos e a encenação em profundidade que permitem ao espectador um certo tempo para a contemplação da cena, esmiuçar e perceber elementos que passariam despercebidos em planos com menor duração. Há também, contudo, o que Martin denomina de "função encantatória dos movimentos de câmera que corresponde, no campo sensorial (sensual), aos efeitos da montagem rápida no plano intelectual (cerebral)." (2007, p. 47, grifo do autor). É o que podemos notar nas cenas citadas: a da performance de Joãozinho e quando ele faz Alfonsina ver o mar. Os movimentos de câmera também substituem a montagem em momentos do filme em que panorâmicas e travellings acompanham personagens e/ou descrevem a paisagem.

\section{Tamanho dos enquadramentos}

$\mathrm{O}$ enquadramento como aspecto em mise en scène está no domínio da cinematografia. De certa forma, ao longo do texto, vimos enfatizando esta questão ao tratarmos da opção do diretor por planos de longa duração. Por trabalharem na mise en scène que privilegia a encenação em profundidade, temos, majoritariamente, em $A$ história da eternidade planos abertos onde a ação (o drama) acontece no segundo ou terceiro plano do quadro. Podemos verificar isso em diversas cenas ilustradas pelas imagens 1 e 2 (na primeira cena do filme); pela imagem 3 (na chegada de Aderaldo à casa de Alfonsina); pelas imagens 17 e 18 (a chegada do neto à casa de Das Dores); pelas imagens 23, 24 e 25 (na performance de Joãozinho); pelas imagens 26, 27 e 28 (no final da festa de aniversário de Alfonsina); apenas para citar alguns exemplos. O tamanho aberto dos planos está em consonância com a necessidade de distanciamento da cena, o que igualmente contribui para ganhos de nitidez no plano e, como resultado, uma encenação em profundidade.

\section{Rimas visuais}

Usamos aqui o termo "rimas visuais" emprestado de Bordwell (2008) para denominar padrões formais (enquadramentos, ângulos, movimentos de câmera etc.) recorrentes em ações dramáticas 
semelhantes. No filme abordado, identificamos esquemas de mise en scène que são "reutilizados" em outros momentos. Comecemos com as cenas das refeições na casa de Alfonsina que, ao todo, estão presentes em três instantes da narrativa. As imagens abaixo representam dois deles que seguem padrões quase exatamente iguais, com leves variações. $O$ enquadramento inicial e o segundo colocam a mesa em uma posição lon- gitudinal em relação ao fundo do cenário com uma mudança de eixo de um para outro de $180^{\circ}$ (Imagens 41 e 42). Em ambas, Alfonsina está de pé ao lado da mesa pronta a servir o pai e os irmãos. O terceiro enquadramento a toma de frente e o pai é visto de perfil (Imagem 43). Esse esquema se repete em mais duas cenas em que a familia está reunida à mesa (Imagens 44, 45 e 46).

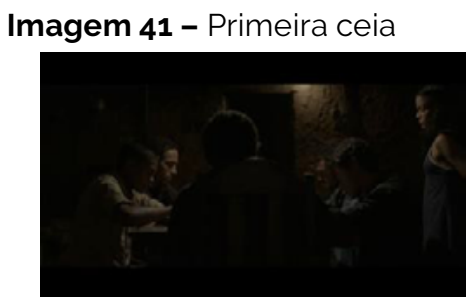

Fonte: Frame do filme A história da eternidade (2014).

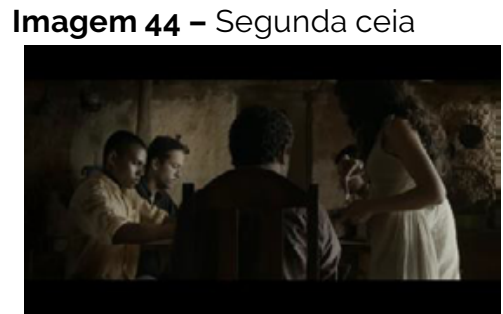

Fonte: Frame do filme $A$ história da eternidade (2014)

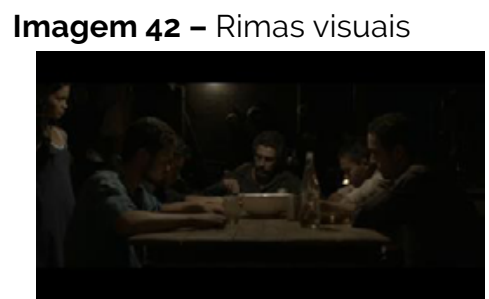

Fonte: Frame do filme A história da eternidade (2014).

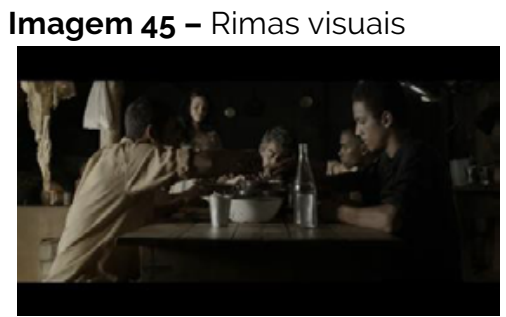

Fonte: Frame do filme $A$ história da eternidade (2014).

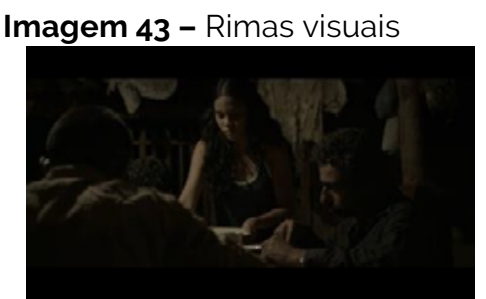

Fonte: Frame do filme A história da eternidade (2014).-

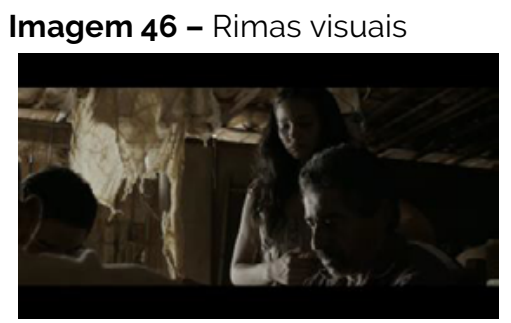

Fonte: Frame do filme A história da eternidade (2014).
Vamos identificar outra rima visual na cena em que Das Dores e seu neto atendem a uma chamada no telefone público. Nas duas cenas há enquadramentos e composições exatamente iguais (Imagens 47, 48, 49 e 50).
Os enquadramentos podem servir à narrativa ainda de outras maneiras. Ao longo de um filme todo, as repetições de certos enquadramentos podem ser associadas a uma personagem ou situação. Isto é, os enquadramentos podem se tornar motivos unificando o filme (BORDWELL; THOMPSON, 2013, p. 311-312).
Imagem 47 - Enquadramento

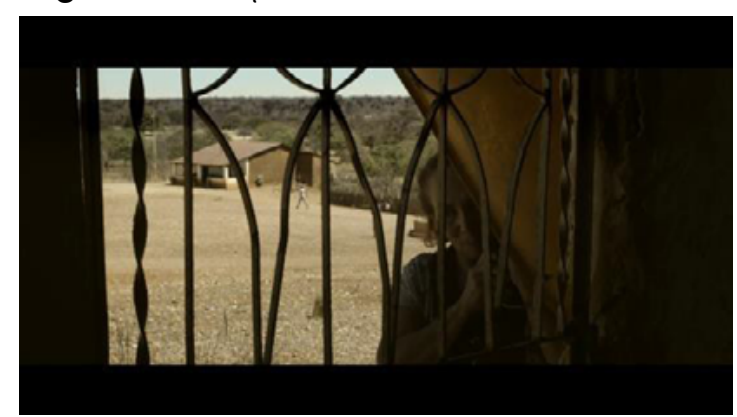

Fonte: Frame do filme A história da eternidade (2014)

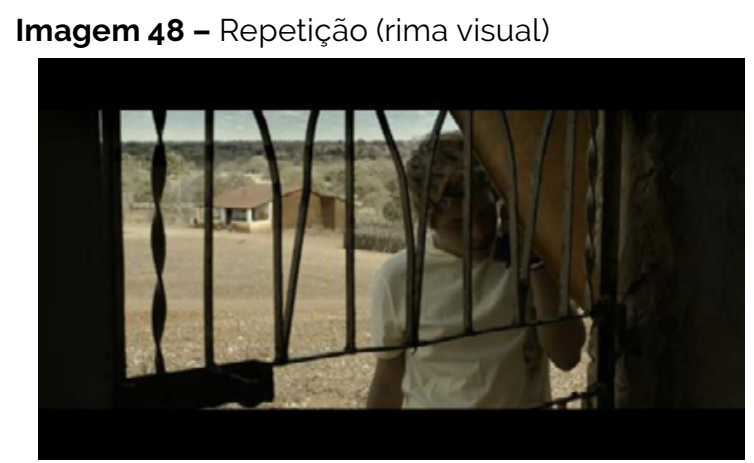

Fonte: Frame do filme A história da eternidade (2014). 


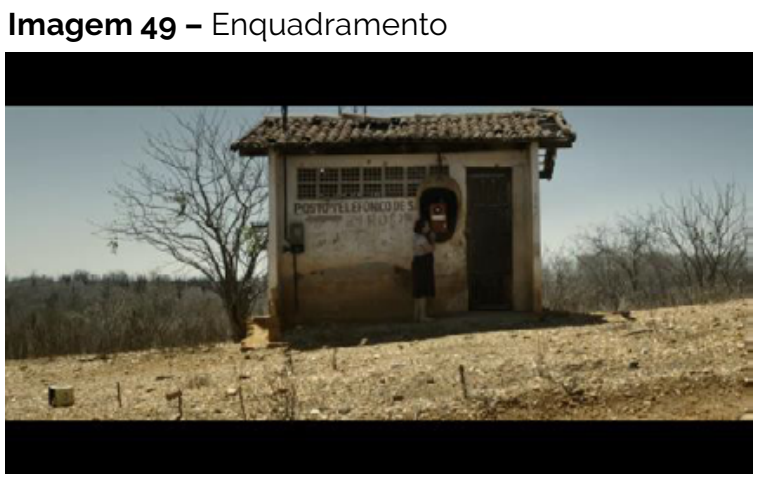

Fonte: Frame do filme A história da eternidade (2014)

As chamadas rimas visuais são apontadas por Bordwell (2008) no filme Elegia de Osaka (MIZOGUCHI, 1936) onde situações semelhantes se repetem com o mesmo tratamento visual (enquadramento, ângulo, composição etc.) estabelecendo ligações entre as cenas, como vimos nos dois exemplos acima. O uso de rimas visuais constitui, como os demais procedimentos tratados aqui, esquemas de encenação adotados por um diretor que podem caracterizar um estilo de narrar cinematograficamente um filme apenas ou um conjunto de filmes de sua filmografia.

\section{Considerações finais}

Tentamos nesse percurso identificar esquemas de mise en scène do longa-metragem A história da eternidade (CAVALCANTE, 2014), estratégias técnicas e estéticas usadas com uma certa regularidade no filme em questão e que vão imprimir um determinado modo de estruturar sua normativa. A mise en scène vai definir como uma história será narrada com as matérias de expressão que o cinema dispõe "(imagem, ruidos, diálogos, menções escritas, música) que tocam como as partes de uma orquestra, ora em unissono, ora em contraponto ou em um sistema de fuga, etc." (GAUDREAULT; JOST, 2009, p. 44).

Camilo Cavalcante compõe sua narrativa, como pudemos constatar, com o uso predominante de planos abertos, posicionando a ação dramática, na maioria das vezes, distanciada da câmera, em planos mais afastados (encenação em profundidade), emoldurando o quadro com elementos da arquitetura do cenário como portas, janelas e pilares, de certa forma tentando
Imagem 50 - Repetição (rima visual)

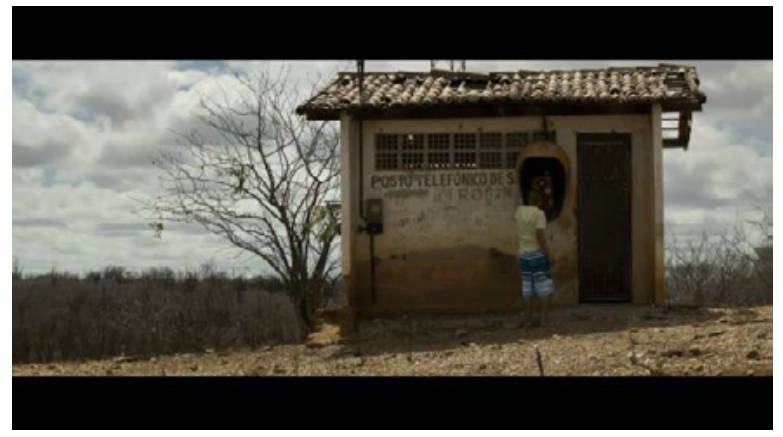

Fonte: Frame do filme A história da eternidade (2014).

arrefecer o drama e não o explicitar. A encenação em profundidade e o tamanho dos planos, como vimos, são procedimentos estilisticos que diretor pernambucano empregou em A história da eternidade, até o momento, seu primeiro longa-metragem. Nos curtas do diretor, em especial, O velho, o mar e o lago (2000), Ave Maria ou a mãe dos sertanejos (2003), Rapsódia para um homem comum (2005), e o ensaio de curta-metragem $A$ história da eternidade (2003) - que emprestaria, onze anos depois, o título ao longa aqui abordado -, verificamos a presença de um ou outro dos esquemas aqui elencados.

Outro esquema de encenação em A história da eternidade é o emprego de planos de longa duração (plano-sequência), evitando, assim, a montagem em continuidade intensificada, uma tônica do cinema industrial mainstream. Esse procedimento se encontra, alguns vezes, associado ao movimento de câmera que, igualmente, substitui a montagem ao se deslocar pelo cenário evitando cortes, ora acompanhando personagens em movimento, ora descrevendo o ambiente. Por fim, como recurso estilistico, temos as rimas visuais que consistem na repetição de situações com os mesmos personagens ou não, reutilizando escolhas estéticas como enquadramento, ângulo e composição. Rotinas técnicas e estéticas, como as identificadas no percurso narrativo do filme em questão, compõem o estilo de uma obra. Quando aplicadas rotineiramente na filmografia de um diretor, elas se tornam uma marca, uma assinatura que pode identificá-lo como autor. No caso de Cavalcante, não arriscamos a afirmar que identificamos um estilo do diretor com a inves- 
tigação de apenas um único longa-metragem, sendo necessário, portanto, que a repetição dos referidos esquemas aconteça em futuras obras.

\section{Referências}

A HISTÓRIA da eternidade. Direção e Roteiro: Camilo Cavalcante. Produção: Aurora Cinema e República Pureza. Intérpretes: Irandhir Santos; Marcélia Cartaxo, Débora Ingrid; Zezita Matos; Leonardo França; Cláudio Jaborandy e outros. Música: Zbigniew Preisner. (120 min), son., color., DCP.

AUMONT, Jacques. O cinema e a encenação. Lisboa: Edições Texto \& Grafia, 2011.

AUMONT, Jacques; MARIE, Michel. Dicionário teórico e crítico de cinema. Campinas, SP: Papirus, 2003.

BORDWELL, David. Sobre a história do estilo cinematográfico. Campinas, São Paulo: Editora da Unicamp, 2013.

BORDWELL, David; THOMPSON, Kristin. A arte do cinema: Uma introdução. Campinas, SP: Editora da USP, 2013.

BORDWELL, David; THOMPSON, Kristin. Figuras traçadas na luz: A encenação no cinema. Campinas, São Paulo: Papirus, 2008.

GAUDREAULT, André; JOST, François. A narrativa cinematográfica. Brasília: Editora Universidade de Brasilia, 2009.

MASCARELLO, Fernando. Cinema hollywoodiano contemporâneo. In: História do cinema mundial. MASCARELO, F (org.). Campinas: Papirus, 2006. p. 333-360.

MARTIN, Marcel. A linguagem cinematográfica. São Paulo: Brasiliense, 1990.

OLIVEIRA JR., Luiz Carlos. A mise en scène no cinema: Do Clássico ao cinema de fluxo. Campinas: Papirus, 2013.

VANOYE, Francis; GOLIOT-LÉTÉ, Anne. Ensaio sobre a análise filmica. Campinas: Papirus Editora, 1994.

XAVIER, Ismail. O discurso cinematográfico: opacidade e transparência. São Paulo: Paz e Terra, 2005.

\section{Bertrand Lira}

Doutor em Sociologia pela Universidade Federal do Rio Grande do Norte (UFRN), em Natal, RN, Brasil. Mestre em Sociologia e graduado em Comunicação Social pela Universidade Federal da Paraiba (UFPB), em João Pessoa, PB, Brasil; professor do Programa de PósGraduação em Comunicação (PPGC) da Universidade Federal da Paraíba (UFPB), em João Pessoa, PB, Brasil.

\section{Endereço para correspondência}

Bertrand Lira

Universidade Federal da Paraiba

Programa de Pós-Graduação em Comunicação

Centro de Ciências Humanas, Letras e Artes

Jardim Cidade Universitária, 58033-455

João Pessoa, PB, Brasil.

Os textos deste artigo foram revisados pela Poá Comunicação e submetidos para validação do autor antes da publicação. 